\title{
Dysfunctional Career Thoughts Minimization: \\ Strategically Improving Student Outlook
}

Connie Browning Budden, (Email: cbudden @ selu.edu), Southeastern Louisiana University

Ellen Bush, Southeastern Louisiana University

Frances B. Wood, Southeastern Louisiana University

\begin{abstract}
Career practitioners have long observed that dysfunctional (negative) career beliefs contribute heavily to the difficulty many college students have in making rational career decisions. This study attempts to measure the impact that a career planning course can have on reducing dysfunctional career thoughts, and thereby increasing the ability of students to focus their career plans. The Career Thoughts Inventory (CTI) was used to assess dysfunctional career thinking before and after students' participation in a three credit hour career planning course. Statistical analyses clearly indicate that dysfunctional career thoughts are significantly reduced through application of an effective career planning course.
\end{abstract}

\section{INTRODUCTION}

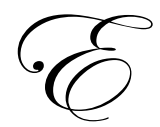

very fall, students entering universities nationwide are bombarded with the age-old question, "What are they planning to study?" For many entering students, regardless of age, gender, ethnicity, and abilities, the answer is often not easy. Current pressures on campus also encourage students to declare early, which often puts the proverbial cart before the horse. Before students make good decisions, they need information about themselves and about the world of work. According to Barefoot and Searcy (1994), the pressure to choose a major is created from (1) the growing concerns over high attrition, and (2) a widespread belief that undecided freshmen are at greater risk for dropping out. Assisting students in making this decision becomes most important when costs continue to increase and government funding continues to decrease (Gibbs, 2000).

Advising first-year students is no simple matter. The diversity of the entering students' profiles regarding age, gender, ethnicity, and abilities continues to complicate the advising process. Additionally, while universities compete for new students, government funding decreases (Gibbs, 2000), and costs continue to increase; therefore, the importance of developing new initiatives and providing services that support student retention and success are more paramount. Advising the diverse population is one of the most important services.

It probably is no surprise that the literature suggests that undecided students tend to drop out of college more frequently than students who are career determined, especially if the undecided fail to receive help with educational and career decisions (Lisansky, 1990). Tinto (1993) postulates that the earlier one attends to students' problems or potential problems, the easier it is to deal with those problems and the less likely it is that the student will withdraw from the university.

Currently, the societal view is that entering students must quickly "find" a vocation where they will achieve their future potential (Schlanger, as cited in Guichard, 2003). While can students are constantly being forced to choose an occupation early, a recent ACT survey (Habley, 2001) reported that $41 \%$ of entering students nationwide indicated a need for help with educational and occupational planning. Although students often feel the pressures from family, society, and the institution concerning choice of major and choice of career, Dumora's work (as cited in Guichard, 2003), along with the research of others (Krumboltz, 1996; Super, 1990), points to the complexity of personal and 
career issues at this stage of development. When students perceive this complexity, according to Dumora, they tend to logically focus on achieving excellence academically which satisfies both family expectations and academic policies, thus allowing them to postpone career decision-making and "finding" a vocation.

In the last twenty-five years, many career theorists have added to the advisor's understanding of career choice and career indecision. For example, Peterson, Sampson, and Reardon (1991) have focused their work on the dynamics of how individuals process information and on their readiness to do so. Understanding these concepts about themselves can impact students in other areas of their lives. Furthermore, Egan (1998) suggests that career counseling also encourages students to "manage their problems in living more effectively" (p.7) by teaching them how to resolve everyday problems themselves, a fundamental point that Chickering referred to as far back as 1969. One of the most effective methods for working with groups of students who need assistance with career decision-making has been the creation of a credit course designed specifically to help this population (Steele, 1994).

Many universities offer career planning courses that have been developed to address the critical need for assisting students with their career development, resulting in increased retention as a by product. Beal \& Noel (1979) suggested that campuses organize for retention since an organized effort would more likely result in success; they continue to recognize the need for proactive strategies today (Noel-Levitz, Inc., 2003). Since research indicates that career planning courses have demonstrated a clear impact upon reducing the number of drop outs at universities and colleges (Goodson, 1982), creating such a course seems a relatively simple way to retain more students. In at least one study, negativism was reduced most in those students who had the highest levels of negative thought processes upon entry into such a course (Reed, Lenz, Reardon and Leierer, 2000); thus, the course had a positive impact on high-risk students.

In reviewing the literature, various studies document the certain effects of career assistance. In 1998 researchers (Sampson, Peterson, Lenz, Reardon, \& Saunders, 1998) conducted a study to assess the effectiveness of an elective career development course. Their conclusions indicated that students completing the course showed a significant decrease in their dysfunctional (negative) career thoughts (commitment anxiety, decision making confusion, and external conflict) as measured by The Career Thoughts Inventory (CTI). A later study indicated that a positive relationship between career courses and cognitive variables exists ( Reed, Lenz, Reardon, \& Leierer, 2001). Still another study found career development course students graduated at a higher rate (81\% compared to $69 \%$ ) than students in general (Folsom, Peterson, Reardon \& Mann, 2002). Hall (2003) found an increase in students retained from fall to fall, as well as an increase in the number of students progressing from freshman to sophomore level. Positive influences of career development courses apparently extend beyond just career information development.

The CTI is comprised of three individual construct scales. First, the Decision Making Confusion (DMC) scale is determined using 14 items which measure an inability to sustain the decision making process due to disabling emotions or a lack of understanding about the decision making process itself. The second measure on the CTI is the Commitment Anxiety (CA) scale. The CA scale contains 10 items that assess the individual's ability to make a commitment regarding a specific career choice. The CA scale recognizes the generalized anxiety accompanying the lack of a commitment to a career choice due to potential outcomes of the decision process, with the concept of anxiety driving the indecision on the part of the student. The last measure, External Conflict (EC), comprised of 5 items, reflects an inability to balance self-perceptions with the importance of input from significant others. The result of the EC concept is a reluctance to assume responsibility for decision-making (Sampson, Peterson, Lenz, Reardon, \& Saunders, 1998).

Administration of the $C T I$ produces four measures for each participant. A measure for each of the three major constructs (DMC, CA, EC) is computed. Finally, the overall CTI is calculated using the scores of the three major constructs. The overall $C T I$ construct is a global indicator of dysfunctional thinking as they relate to career problem solving and the career decision-making process. It is the use of the CTI that drives the assessment of the usefulness of career planning courses in impacting the career decision-making process. Thus, the $C T I$ is seen as a useful and valid assessment of the effectiveness of retention and progression efforts. 


\section{METHODOLOGY}

The Career Thoughts Inventory is being used to assess changes in the ability of students to focus their efforts on a career choice pursuant to their completing the university's career planning course. The Career Thoughts Inventory was selected as a measurement tool because it could be easily administered before and after students took the course and due to its relevance when assessing student career decision making. The CTI allowed an easy statistical testing platform that would identify changes in dysfunctional (negative) career thoughts at the completion of the course. The instrument was used in a career planning course at a mid-sized, 4-year public university in the South. The majority of students in the class were undecided majors.

In the Fall 2002 and Spring 2003 semesters, sixteen career planning courses were selected for participation in the analysis. The CTI was administered at the beginning of the semesters to all students in the selected courses. At the conclusion of the semester, each student was given the $C T I$ as a retest. Paired t-tests were conducted to assess the impact of the course on the career development of the students.

A total of 480 students completed the pre- and post-test assessments. The sample was made up of 246 males and 245 females. Paired t-tests were used to test the null hypothesis that the mean scores of the pre and post CTI administration are equal. A finding that the null hypothesis should be rejected indicates that the means are not equal implying that the course itself changed student attitudes. A finding that the null hypothesis should be accepted would indicate that the course had no impact on attitudes relative to career choice.

\section{FINDINGS AND DISCUSSION}

Findings indicate that there are significant decreases in dysfunctional (negative) career thoughts in students who successfully completed the career planning course. The Career Thoughts Inventory's (CTI) computed t-statistic of 7.87 was found to be significant at much better than the .01 level. The null hypothesis should be rejected indicating that the means of the measures of the pre-test and post-test were not equal. There is a significant difference between the attitudes of students prior to taking the course compared to those same students who completed the course. The CTI pre-test had a mean measurement of 56.1. The post-test $C T I$ measure was 46.8 . The significance of the difference (9.23333) is apparent. The course had a positive impact on student attitudes and reduced tension associated with career decision-making. Further, as one would expect with such a significant difference in measures, the correlation between the pre-test and post-test scores as indicated by the Pearson Correlation Coefficient was low.

Table 1: CTI Total Statistics (i)

\begin{tabular}{lcc}
\hline & Variable 1 & Variable 2 \\
\hline Mean & 56.10625 & 46.87292 \\
Variance & 349.043 & \\
Observations & 480 & \\
Pearson Correlation & .222957 & \\
T Statistic & 7.873119 & \\
$\mathrm{P}(\mathrm{T}<=\mathrm{t})$ & $1.17 \mathrm{E}-14$ & \\
$\mathrm{~T}$ Critical & 1.648041 & 9.233330 \\
Difference in means & & \\
\hline
\end{tabular}

$$
* \mathrm{p} \# .01
$$

Based upon the findings that the course had a significant impact on students' dysfunctional career thoughts, it may be concluded that the improvement in student attitudes towards career choices and opportunities frees them to move forward in their career decisions. In looking more closely at individual attributes that make up the CTI, one can see that the three sub-measures were all significantly reduced as a result of the course. The Commitment Anxiety (CA) measure had a pre-test mean of 15.60625 and a post-test of 13.48542 . The p-value of 2.09E-11 indicates that the null hypothesis, that the means are equal, should be rejected. Students reduced their commitment anxiety by completing the course. The Pearson Correlation indicated low correlation between the measures at .193662. 
Table 2: Commitment Anxiety Statistics (CA)

\begin{tabular}{lcc}
\hline & Variable 1 & Variable 2 \\
\hline Mean & 15.60625 & 13.48542 \\
Variance & 27.19119 & \\
Observations & 480 & \\
Pearson Correlation & 0.193662 & \\
T Statistic & 6.75368 & \\
P(T<t) & $2.09 \mathrm{E}-11$ & 2.1208 \\
T Critical & 1.648041 & \\
Difference in means & & \\
\hline * \# 01 & &
\end{tabular}

The decision making confusion (DMC) sub-measure of the test was found to have been significantly reduced as well. The difference between the pre-test and post-test of 2.585420 was a statistically significant reduction, indicating that the course reduced tension related to decision making. Again, correlation between the pre-test and posttest was low as indicated by the Pearson Coefficient. The low correlation is expected, given that the mean scores are significantly different.

Table 3: Decision Making Confusion Statistics (DMC)

\begin{tabular}{lcc}
\hline & Variable 1 & Variable 2 \\
\hline Mean & 13.49167 & 10.90625 \\
Variance & 53.6993 & \\
Observations & 480 & \\
Pearson Correlation & 0.243501 & \\
T Statistic & 6.117665 & \\
P(T<=t) & $9.87 \mathrm{E}-10$ & 2.585420 \\
T Critical & 1.648041 & \\
\hline Difference in means & &
\end{tabular}

Pre-test and post-test findings of the External Conflict (EC) sub-measure indicate that the null hypothesis should be rejected. The means are significantly different. The difference of 0.931250 is statistically important. Correlation between the measures was very low. The reduction in mean measures indicates that the course reduced student tension related to external conflict, and once again allowed students to improve their career-related thought processes.

Table 4: External Conflict Statistics (EC)

\begin{tabular}{lcc}
\hline & Variable 1 & Variable 2 \\
\hline Mean & 5.079167 & 4.147917 \\
Variance & 16.13986 & \\
Observations & 480 & \\
Pearson Correlation & 0.194013 & \\
T Statistic & 4.52194 & \\
$\mathrm{P}(\mathrm{T}<=\mathrm{t})$ & $3.87 \mathrm{E}-06$ & .931250 \\
$\mathrm{~T}$ Critical & 1.648041 & \\
\hline Difference in means & & \\
\hline$* \mathrm{p} \# .01$ & &
\end{tabular}

Pre-test and post-test measures using the Career Thoughts Inventory allowed an assessment of course impact. The Career Planning Course that was utilized as an intervening variable indicates that it can have a significant impact on reducing student tensions related to uncertainties and anxiety surrounding the career decision process. Each of the 
sub-measures was reduced as a result of the course. As would be expected given that each sub-measure was reduced, the overall $C T I$ score was reduced. The reductions were statistically significant.

Based upon the findings of this study it is evident that a career planning course can have a strong impact upon reducing the pressures associated with the career decision making process. It follows, therefore, that when these pressures are alleviated, when students are no longer experiencing a "crisis of imagination" (Amundson, 2002, p. 140) concerning their future plans, then they are better able to move forward with their career decisions, resulting in progression and retention. In light of this, colleges and universities might be well-served by adding, or even requiring, a career planning course as part of their curricula.

\section{IMPLICATIONS FOR FUTURE RESEARCH}

The focus of further research should be on the extent to which career planning courses impact student retention and progression. Increasingly, state legislators and boards of higher education are demanding accountability in the form of increased graduation rates. Lack of student progression and its' related impact on drop-out rates and stop-out rates, negatively impacts graduation rates.

Efforts to increase graduation rates may include effective career planning courses in the event analyses indicate their applicability as an effective progression tool. In addition, the impact of such variables as student classification, course delivery methods, gender of participants, age, socio-economic background, major, admission scores, and ethnicity should be investigated to determine if the impact of the course is consistent across these measures.

Finally, because students who change majors constitute a larger group of students than those who enter undecided in many institutions (Steele, 1994), additional study could include a sample of students with declared majors. Students whose needs are met early and actively by their institution are more likely to be successful and to persist, assisting students in choosing a career is an efficient use of the University's resources and would simultaneously move students toward graduation.

\section{REFERENCES}

1. Amundson, N. E. (2002). Coloring outside the lines: Boundary issues for counselors. Journal of Employment Counseling, 39(3), 138-144.

2. Barefoot, B. O. \& Searcy, D. N. (1994). Freshman seminars and other courses for the undecided student (Monograph No. 15).Columbia, SC: University of South Carolina, National Resource Center for The Freshman Year Experience.

3. Beal, P. E. \& Noel, L. (1979). What Works in Student Retention. The American College Testing Program and the National Center for Higher Education Management Systems.

4. Chickering, A. (1969). Education and identity. San Francisco: Jossey-Bass.

5. Egan, G. (1998). The skilled helper: A problem management approach to helping (6 ${ }^{\text {th }}$ ed.). Pacific Grove, CA: Brooks/Cole.

6. Folsom, B., Peterson, G.W., Reardon, R.C., \& Mann, B.A. (2002). The impact of a career course on retention and academic performance (Technical Report 34). Retrieved March 15, 2003, from: http://www.career.fsu.edu/techcenter

7. Gibbs, A. (2000, June). Changing government roles relative to higher eduation. ACPA [On-line serial]. http://www.acpa.nche.edu/seniorscholars/trendstrends9.htm

8. Goodson, W. D. (1982, March). A career class does have an impact - A ten year follow-up. The American Personnel and Guidance Association. (ERIC).

9. Guichard, Jean. (2003). Career counseling for human development: An international perspective. The Career Development Quarterly, 51, 306-321.

10. Habley, W. (2001, January). Academic advising for retention. Paper presented at the ACT Advising Workshop, Baton Rouge, LA. 
11. Hall. M. (2003). Progression and retention of students taking CPL 104. Unpublished raw data, Southeastern Louisiana University.

12. Krumboltz, J. D. (1996). A learning theory of career counseling. In M. Savickas \& B. Walsh (Eds.), Integrating career theory and practice (pp. 233-280). Palo Alto, CA: CPP Books.

13. Lisansky, R. S. (1990). The effect of cognitive style of decision-making, level of career decidedness and completion of the life and career planning course on retention rate of undecided entering traditional-age college freshmen. Retrieved March 13, 2002 from the World Wide Web:

http://www.spweb.silverplatter.com/louis

14. Noel-Levitz. (2003). 2001-2002 National enrollment management survey: Executive summary. Iowa City: Noel, Levitz.

15. Peterson, G. W., Sampson, J. P., Jr., \& Reardon, R. C. (1991). Career development and services: A cognitive approach. Pacific Grove, CA: Brooks/Cole.

16. Reed, C.A., Lenz, J.G., Reardon, R.C., \& Leierer, S.J. (2000). Reducing negative career thoughts with a career course: Technical Report No. 25. Retrieved May 7, 2001 from: http://www.career.fsu.edu/techcenter/

17. Reed, C. A., Lentz, J. G., Reardon, R. C., \& Leierer, S. J. (2001, December). A cognitive career course: From theory to practice. The Career Development Quarterly, 50, 2, 158-168.

18. Sampson, J.P. Jr., Peterson, G.W., Lentz, J.G., Reardon, R. C., \& Saunders, D. E. (1998). The design and use of a measure of dysfunctional career thoughts among adults, college students, and high school students: The Career Thoughts Inventory [Electronic version]. Journal of Career Assessment, 6, 115-134.

19. Steele, George E., (1994). Major changers: A special type of undecided student (Monograph No. 15). Columbia, SC: University of South Carolina, National Resource Center for The Freshman Year Experience.

20. Super, D. E. (1990). A life-span, life space approach to career development. In D. Brown \& L. Brooks (Eds.), Career choice and development: Applying contemporary theories to practice ( $2^{\text {nd }}$ ed., pp. 121-178). San Francisco: Jossey-Bass.

21. Tinto, V. (1993). Leaving college: Rethinking the causes and cures of student attrition. Chicago: University of Chicago Press. 